\title{
Morphology and sediment deformation of downslope Brasilichnium trackways on a dune slipface in the Nugget Sandstone of northeastern Utah, USA
}

\author{
George F. Engelmann and Daniel J. Chure
}

\begin{abstract}
The presumed synapsid trackway known as Brasilichnium is known by numerous trackways from many localities throughout the eolian deposits of the Late Triassic to Early Jurassic erg that covered much of the western United States. These trackways occur primarily on the foreset beds of dunes. The overwhelming majority of the trackways were made by animals traveling up slope. A slab of Nugget Sandstone exhibited in the Department of Geology and Geophysics at the University of Utah preserves at least 17 Brasilichnium trackways, 13 going up slope and four going down slope. The downslope tracks have a distinctive morphology consisting of a raised anterior pressure pad ahead of, and a posterior collapse depression behind, a small, poorly preserved impression of the foot. The anterior pressure pad can be explained as a low angle thrust driven forward by the impact of the foot, whereas the posterior depression is a downslope slump as the foot was withdrawn. This interpretation is supported by the observation on an outcrop in Dinosaur National Monument of similar features in a Brasilichnium trackway that traverses the slope, and by studies of tracks made by other vertebrates in eolian sands. The enormous preponderance of upslope over downslope trackways in eolian sandstones remains an open question. The distinctiveness of the downslope track morphology and the fact that they are well preserved in the studied material, however, suggests that the answer is something more than coincidence or preservation bias.
\end{abstract}

George F. Engelmann. Department of Geography and Geology, University of Nebraska at Omaha, 60th \& Dodge Street, Omaha, NE 68182, USA. gengelmann@unomaha.edu Daniel J. Chure. Dinosaur National Monument, Box 128, Jensen, UT 84035, USA. dan_chure@nps.gov

Keywords: Brasilichnium; Nugget Sandstone; Triassic-Jurassic; eolian; ichnology; trackways

Submission: 3 December 2015 Acceptance: 21 April 2017

Engelmann, George F. and Chure, Daniel J. 2017. Morphology and sediment deformation of downslope Brasilichnium trackways on a dune slipface in the Nugget Sandstone of northeastern Utah, USA. Palaeontologia Electronica 20.2.22A: 1-21 palaeo-electronica.org/content/2017/1845-downslope-trackways

Copyright: @ May 2017 Society of Vertebrate Paleontology. This is an open access article distributed under the terms of the Creative Commons Attribution License, which permits unrestricted use, distribution, and reproduction in any medium, provided the original author and source are credited.

creativecommons.org/licenses/by/4.0/ 


\section{INTRODUCTION}

During the Late Triassic through Early Jurassic, the western United States was covered by a vast erg system, with an estimated extent of 2.2 million $\mathrm{km}^{2}$ and a total dunefield area larger than that of the modern day Sahara (Kocurek and Dott, 1983; Milligan, 2012). The source for the sand was deflating floodplains associated with an Amazonlike transcontinental river originating in the Appalachian Mountains and terminating in western Canada (Dickinson and Gehrels, 2010). Sediments of this erg system are known as the Nugget, Navajo, or Aztec sandstones depending on their geographic location.

Despite a seemingly inhospitable environment, both trace and body fossils indicate that life could be locally diverse and abundant (Chure et al., 2014). Skeletal remains are known from interdunal deposits, but the fossil record in the dunes consists solely of trace fossils. Brasilichnium, a track attributed to tritylodonts (Rowland and Mercadante, 2014), is by far the most common vertebrate ichnofossil in dune sediments of the Late Triassic-Early Jurassic erg deposits of the Nugget Sandstone and its equivalents, the Navajo and Aztec sandstones. It is widespread both geographically and stratigraphically (Buss, 1921; Faul and Roberts, 1951; Albers, 1975; Lockley and Hunt, 1995; Rainforth and Lockley, 1996; Rainforth, 1997; Lockley, 2005; Reynolds, 2006a, 2006b; Engelmann et al., 2010; Engelmann and Chure, 2011; Lockley, 2011; Lockley et al., 2011; Chure et al., 2014; Good and Ekdale, 2014; Rowland and Mercadante, 2014; Rowland et al., 2014) and is the namesake of the Brasilichnium dune ichnofacies (Lockley et al., 1994, 2011; Rainforth and Lockley, 1996; Hunt and Lucas, 2007; Lockley, 2007). In spite of the abundance of Brasilichnium, skeletal remains of the putative trackmaker, tritylodonts, are exceedingly rare in these erg deposits (Winkler et al., 1991).

Although numerous Brasilichnium trackways are known, nearly all record the trackmaker moving up slope on the lee side of a dune. This is true regardless of the number of trackways at a site, even when individual Brasilichnium tracks number in the hundreds (Lockley, 1991, figure 10.2; Engelmann et al., 2010; Engelmann and Chure, 2011; Rowland and Mercadante, 2014). The reasons for this apparent lack of downslope trackways are uncertain; however, a slab at the University of Utah (UUIC 1873) clearly records multiple Brasilichnium trackways traveling down slope that exhibit distinctive and characteristic sediment deformation. Here we describe the slab, the associated deformation, and a trackway from Dinosaur National Monument showing similar features.

\section{INSTITUTIONAL ABBREVIATIONS}

BYU, Brigham Young University, Provo, Utah, USA; DINO, Dinosaur National Monument acronym for museum specimens; UUIC, Ichnology Collection, Department of Geology and Geophysics, University of Utah, Salt Lake City, USA.

\section{DESCRIPTION}

\section{UUIC 1873}

UUIC 1873 is a slab of reddish sandstone with maximum measurements of $121 \mathrm{~cm} \times 141 \mathrm{~cm}$ and bearing abundant track impressions. It is currently on exhibit on the second floor of the Frederick Albert Sutton Building, home of the Department of Geology and Geophysics at the University of Utah in Salt Lake City, Utah (Figure 1, Appendix 1).

The provenance of the slab is somewhat problematic. It was being stored in a basement room of the old Utah Museum of Natural History at the University of Utah campus when A.A. Ekdale arrived as a faculty member in 1974 . How long it had been there is unknown. There were no data associated with it, and it was not accessioned and catalogued in the UUIC until sometime after 1974 (Ekdale personal commun., 2015). The grain size, color, and bedding are consistent with other footprint-bearing slabs from the Nugget Sandstone. The Nugget is a source of building stone that has been widely used in Salt Lake City and on the University of Utah campus, and there have been numerous nearby Nugget stone quarries in the Wasatch Mountains (Red Butte Canyon, Parley's Canyon, and around the city of Heber). Many of these quarries produced vertebrate and invertebrate ichnofossils (Albers, 1975; Stokes, 1978; Chure et al., 2014)

The UUIC contains about two dozen specimens of the Nugget Sandstone bearing vertebrate and invertebrate ichnofossils from the American Stone Quarry near Heber, UT, that were collected as part of a 1975 Master's thesis (Albers, 1975; Chure et al., 2014). Although UUIC 1873 was not specifically mentioned by Albers, her specimens (both the rock and the traces) compare well with UUIC 1873. We have visited exposures of the Nugget near the American Stone Quarry and have observed a strong similarity between the lithology at that quarry and UUIC 1873. We are confident that UUIC 1873 is from the Nugget Sandstone and 

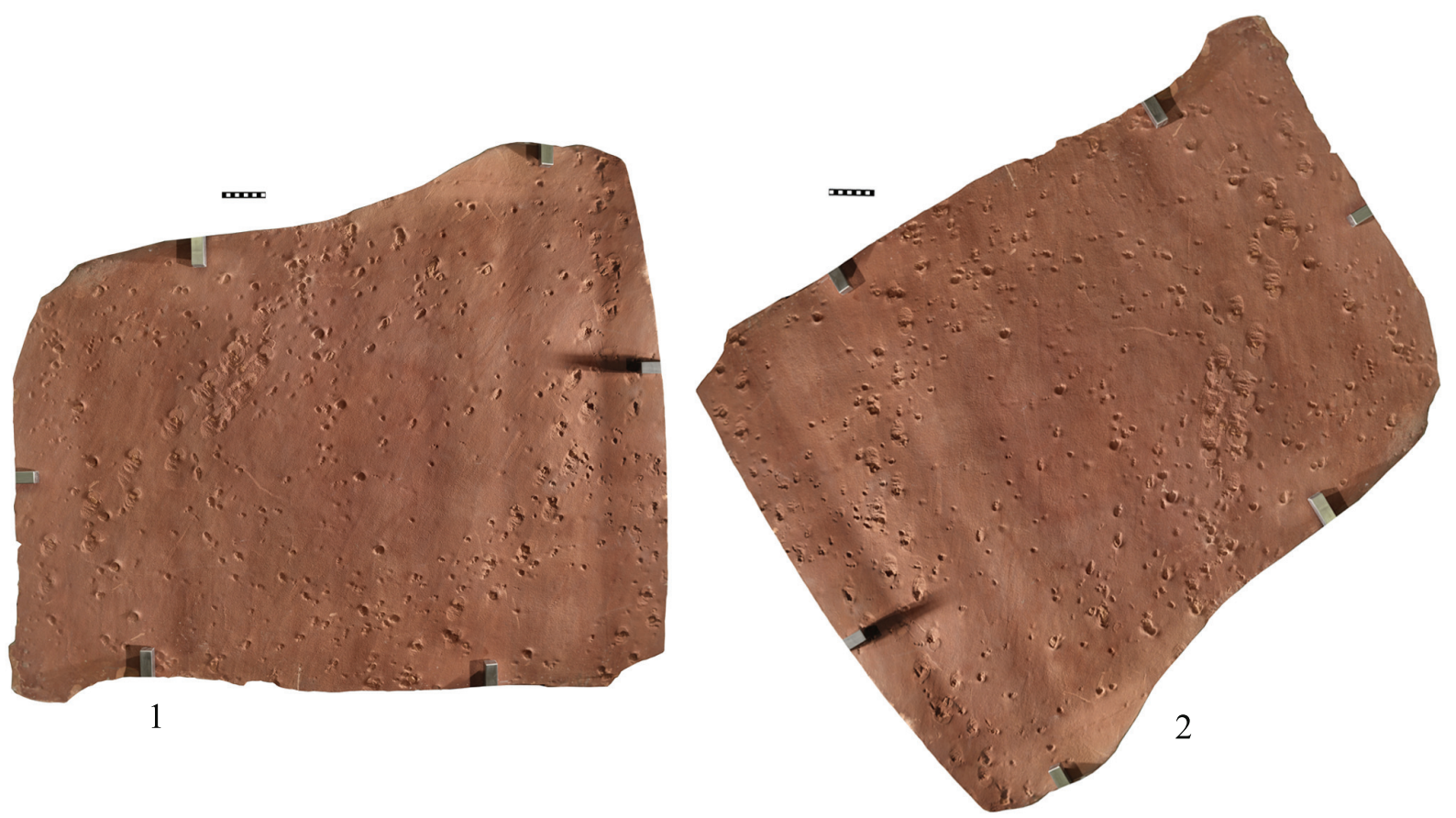

FIGURE 1. UUIC 1873, slab of Nugget Sandstone bearing multiple trackways. 1, the slab as it is exhibited in the halls of the Frederick Albert Sutton Building of the University of Utah in Salt Lake City. 2, image of the slab rotated $150^{\circ}$ clockwise to show the trackways in their original orientation. Scale bars equal $10 \mathrm{~cm}$.

likely came from one of the quarries in the Heber area.

UUIC 1873 was deposited on the lee slope of a sand dune. Push-up rims along the posterior margin on many of the tracks on the slab support the interpretation that the sand layers maintained a primary slope at the time the tracks were made. UUIC 1873 also bears low amplitude wind ripples across its surface. The crests of these ripples were oriented parallel to dip direction of the original lee surface. Using the push-up rims and wind ripples, we can establish the original orientation of sediments on the slope which is different from the way the slab is mounted for exhibit. To place the slab in its depositional orientation it should be rotated about $150^{\circ}$ clockwise (Figure 1.2). Throughout this paper we will describe and refer to the slab and tracks in terms of their original depositional orientation.

Nearly 400 tracks are preserved on the UUIC 1873 (Figure 2, Appendix 2); all preserved trackways terminate abruptly at the slab's margins. This is the densest occurrence of vertebrate tracks from Nugget dune foreset beds that we are aware of, being approached only by a site near Dinosaur National Monument (Engelmann and Chure, 2011).
Only one trackway is not of vertebrate origin. On the left side of the slab there is a partial trackway consisting of two parallel rows of groups of three or four closely spaced impressions (Figures 2,3 ). We refer this trackway to the ichnogenus Paleohelcura, a trace made by both scorpions and spiders (Sadler, 1993; Braddy, 1995; Davis et al., 2007). Paleohelcura is a common arthropod trace fossil on dune foreset beds in Permian through Early Jurassic erg deposits, including the Nugget (Lockley et al., 1995; Chure et al., 2014).

All other traces on UUIC 1873 are of vertebrate origin and referable to Brasilichnium, a common trackway on dune foreset beds in the Nugget, its equivalents, and other Mesozoic eolianites (Reynolds, 2006a, 2006b; Lockley, 2011; Chure et al., 2014; Rowland and Mercadante, 2014) that is attributed to therapsids. Brasilichnium is a quadrupedal trackway lacking a tail drag with manus impressions smaller than pes impressions; both manus and pes prints are wider than long, with rounded heel margins (Haubold, 1971; Leonardi, 1981; Fernandes and Carvahlo, 2008; Lockley, 2011). In UUIC 1873 pes prints have three, or sometimes four, short and stubby digit impressions. This difference in digit count reflects the sub- 


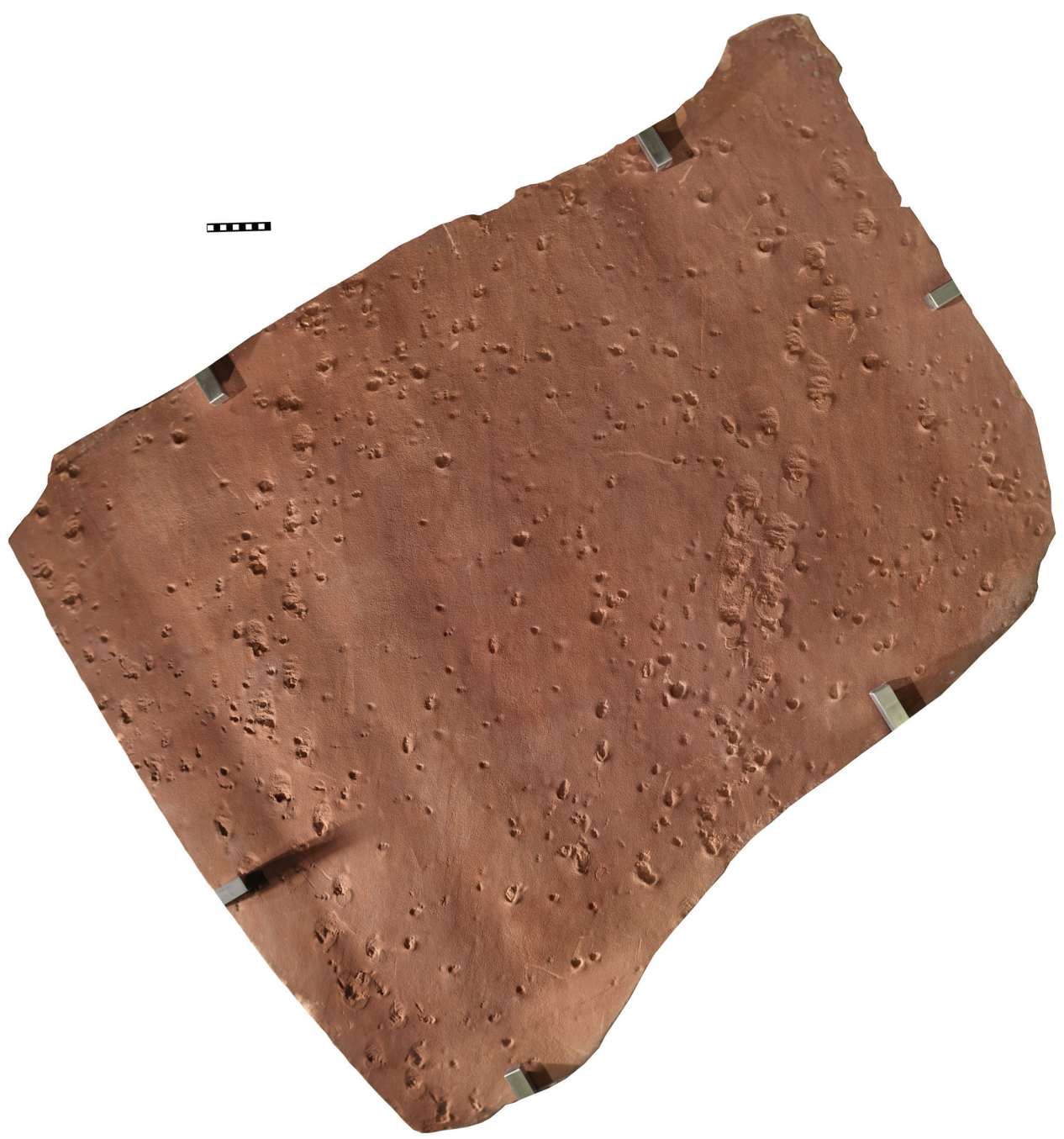

FIGURE 2. High resolution image of UUIC 1873. Scale bar equals $10 \mathrm{~cm}$.

optimal nature of vertebrate tracks found in eolian deposits (Haubold et al., 1995; Morales and Haubold, 1995). Manus impressions are rare on UUIC 1873 , but that is a common absence in many occurrences of Brasilichnium and is attributable to factors such as: 1) the small size of the manus and its shallower impressions; 2) that most trackways are probably undertracks with less potential to show the shallower prints in a trackway; 3 ) overprinting of manus tracks by the pes; and 4) differences in gait (Leonardi, 1981; Lockley and Hunt, 1995, figure 4.23; Lockley, 2011; Chure et al., 2014; Rowland and Mercadante, 2014).

A number of Brasilichnium tracks on UUIC 1873 consist solely of small, circular toe impressions of the pes, sometimes in a slightly arched arrangement. These are deep undertracks where only the toe impressions are present, some still filled with matrix. Individual Brasilichnium track sizes on the slab range from a pes width of $7 \mathrm{~mm}$ to $32 \mathrm{~mm}$. The former is among the smallest therapsid/mammaloid tracks reported from the Jurassic (Lockley et al., 2011).

At least 17 trackways can be identified on UUIC 1873, 13 of which are going up slope (Figures 2,3 ). In addition to these trackways, there are numerous other tracks in isolation, which are probably deeper undertracks from a stratigraphically higher level above the preserved surface of the slab. Four trackways are unusual in being made by therapsids traveling down slope and show sediment deformation distinctly different than that seen in upslope trackways. 


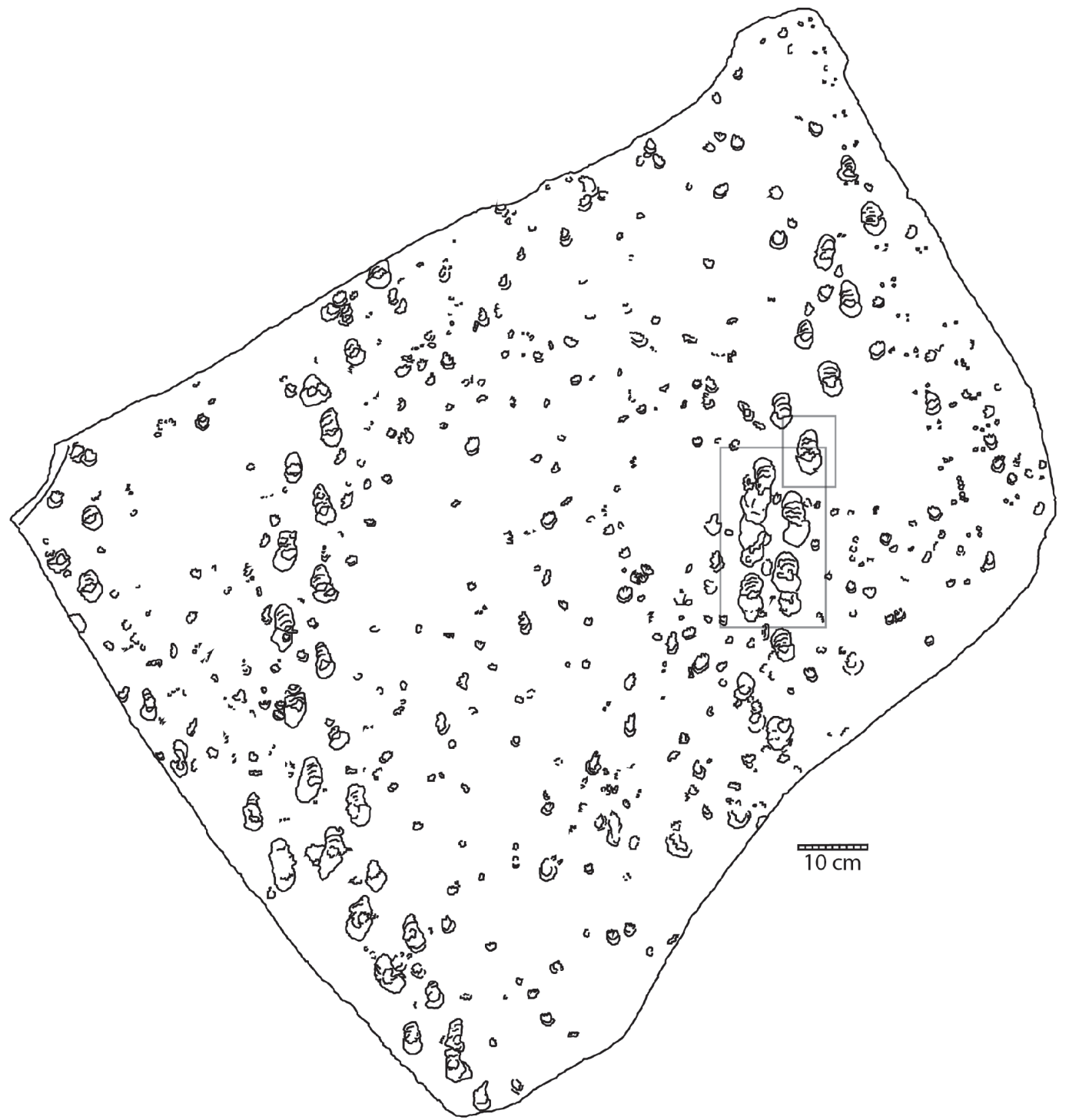

FIGURE 3. Map of tracks and trackways on UUIC 1873 . Scale bar equals $10 \mathrm{~cm}$.

The entire UUIC 1873 slab is represented by a Gigapan image that is a composite of 80 closeup photographs. This Gigapan image formed the basis for images of the slab presented in Figures 1 and 2 . These images show regularly spaced bands of tonal variation across the surface of the slab, which are artifacts of the process of compiling many images with slight differences in exposure across the subject. See Appendix 1 for information about a larger version of this image.

\section{Transverse Trackway, Dinosaur National Monument Locality 490}

Dinosaur National Monument paleontological locality 490 (Figure 4) is located in the Nugget Sandstone in the Utah portion of Dinosaur National
Monument (site details are in the locality files at Dinosaur National Monument). It preserves multiple vertebrate (Brasilichnum) and invertebrate (Octopodichnus, Paleohelcura) trackways (Figures 5 and 6 , Appendices 3 and 4). The track-bearing bedding surface is about $4 \mathrm{~m}^{2}$. The tracks are in dune foreset beds bearing faint wind ripples oriented parallel to dip direction of the original lee surface. Nugget outcrops are discontinuous in the area of locality 490 , so the site's stratigraphic level is somewhat uncertain; however, the locality is from the middle $50 \%$ of the Nugget, the part of the section dominated by dune deposits.

Most of the trackways are heading up slope, showing push-up rims along their posterior margins. An exception is a single trackway, $2.7 \mathrm{~m}$ in 

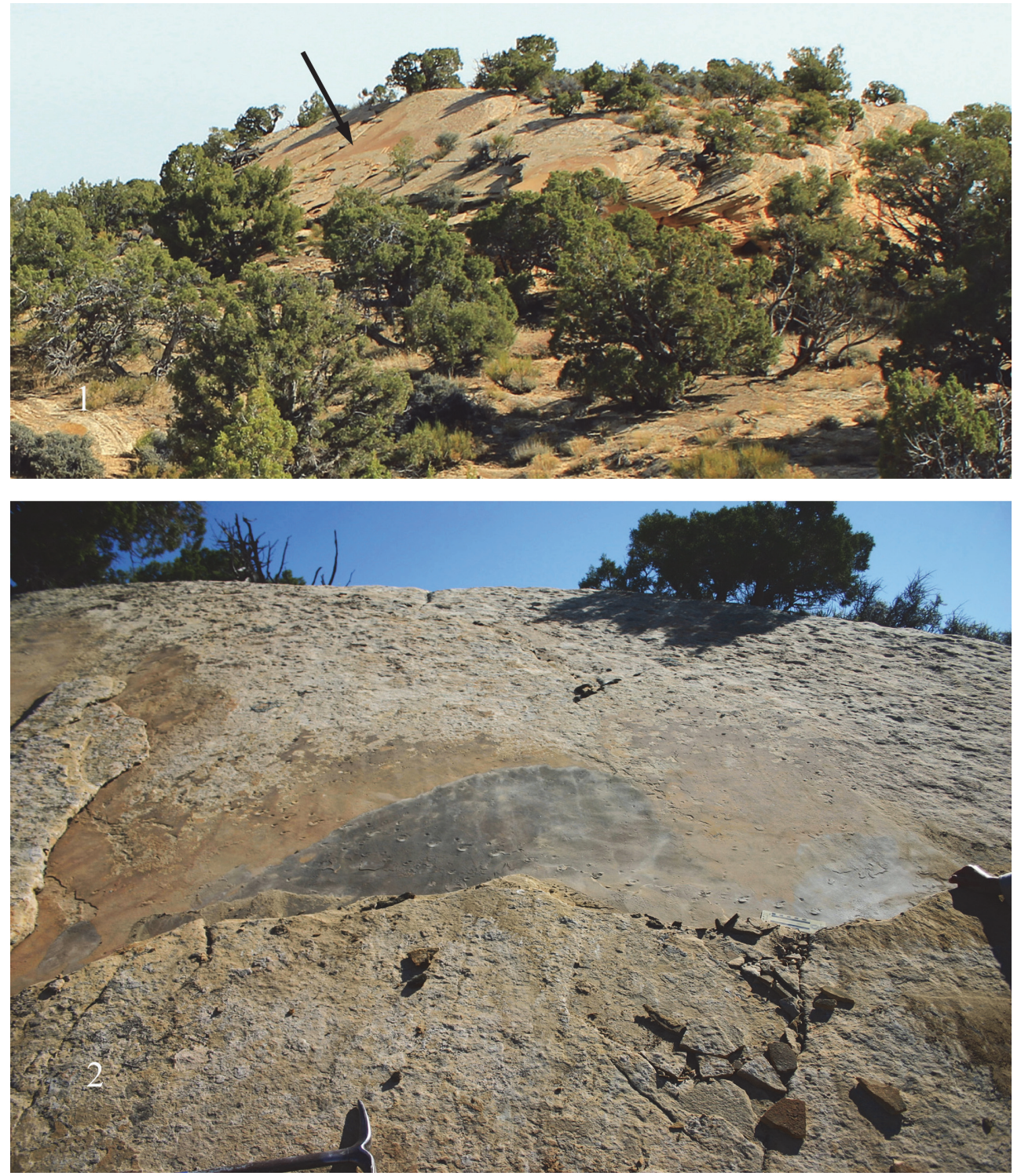

FIGURE 4. Distant and near views of locality DNM 490. 1, site as approached from the southeast. Arrow points to track bearing surface. 2, the track surface of 490 is the large bedding plane surface on the erosional remnant of Nugget Sandstone.

length, which traverses the surface at a high angle to the original dip direction. This transverse trackway (Figures 5-10, Appendices 3-5) shows a number of peculiar features that complement our observations on the downslope trackways on UUIC 1873. Our description, observations, and images are based on the outcrop and original fossils. The nature of the outcrop, however, is such that collecting specimens is not possible. In lieu of collecting, we have molded the entire length of the transverse trackway, and a cast (DINO 40699) has been deposited in the monument's museum collection.

\section{ANALYSIS OF DOWNSLOPE TRACKWAYS}

\section{Track Morphology and Dynamics of Track Formation}

Two relatively long trackways on UUIC 1873 and two shorter ones show a distinctive morphology compared to the more abundant tracks made by animals traveling up slope. We interpret these trackways as the traces left by animals travelling down slope.

Individual tracks made by animals travelling up slope often show toe or claw impressions more or less distinctly preserved on the upslope margin 


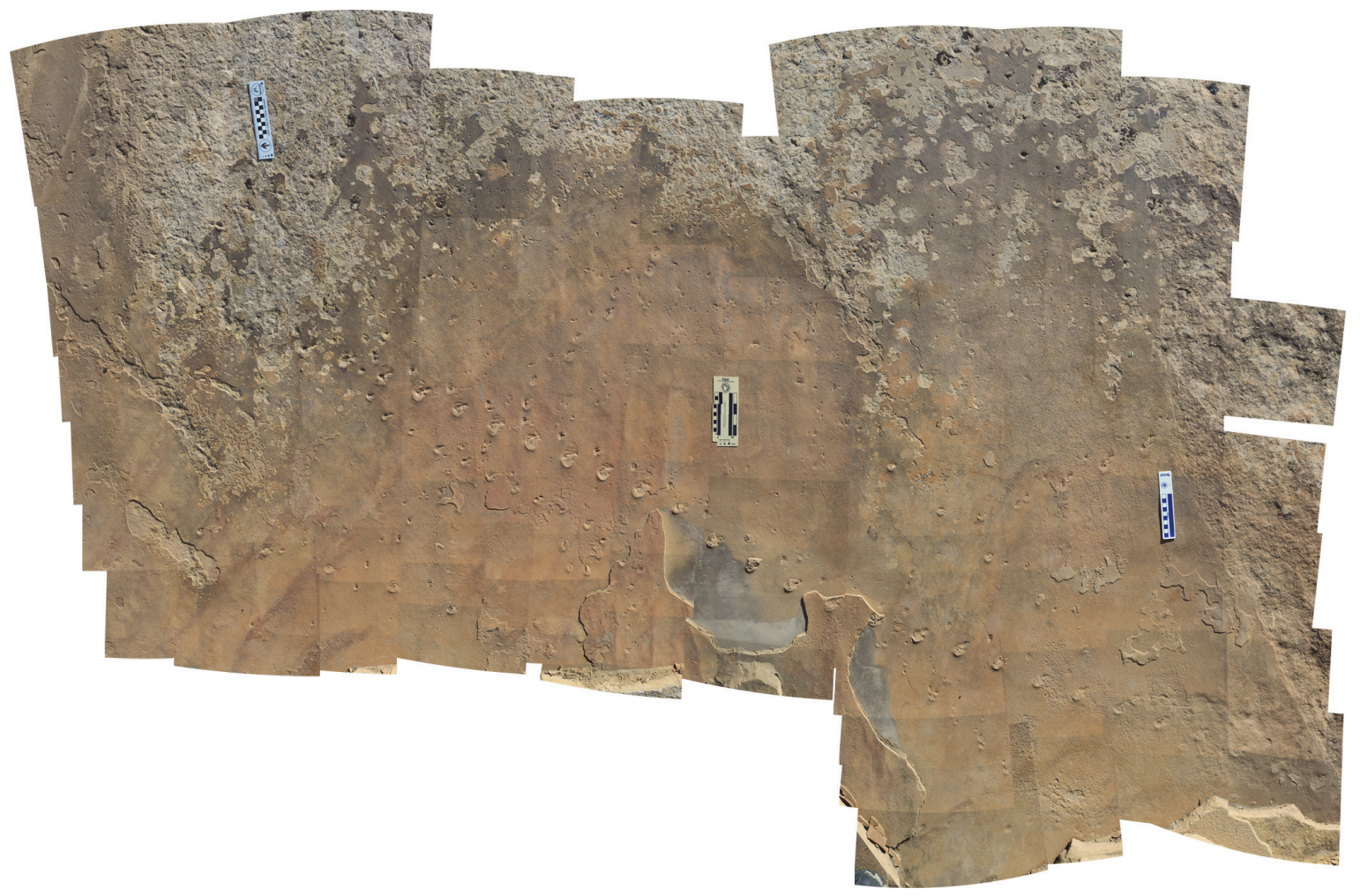

FIGURE 5. Composite photograph of the track-bearing surface of DNM 490. The crests of wind ripples are evident, especially near the center of the image, and provide a good indication of the primary dip direction of the slope of the dune. Scale bars equal $10 \mathrm{~cm}$. Center scale bar distorted by photo stitching process.

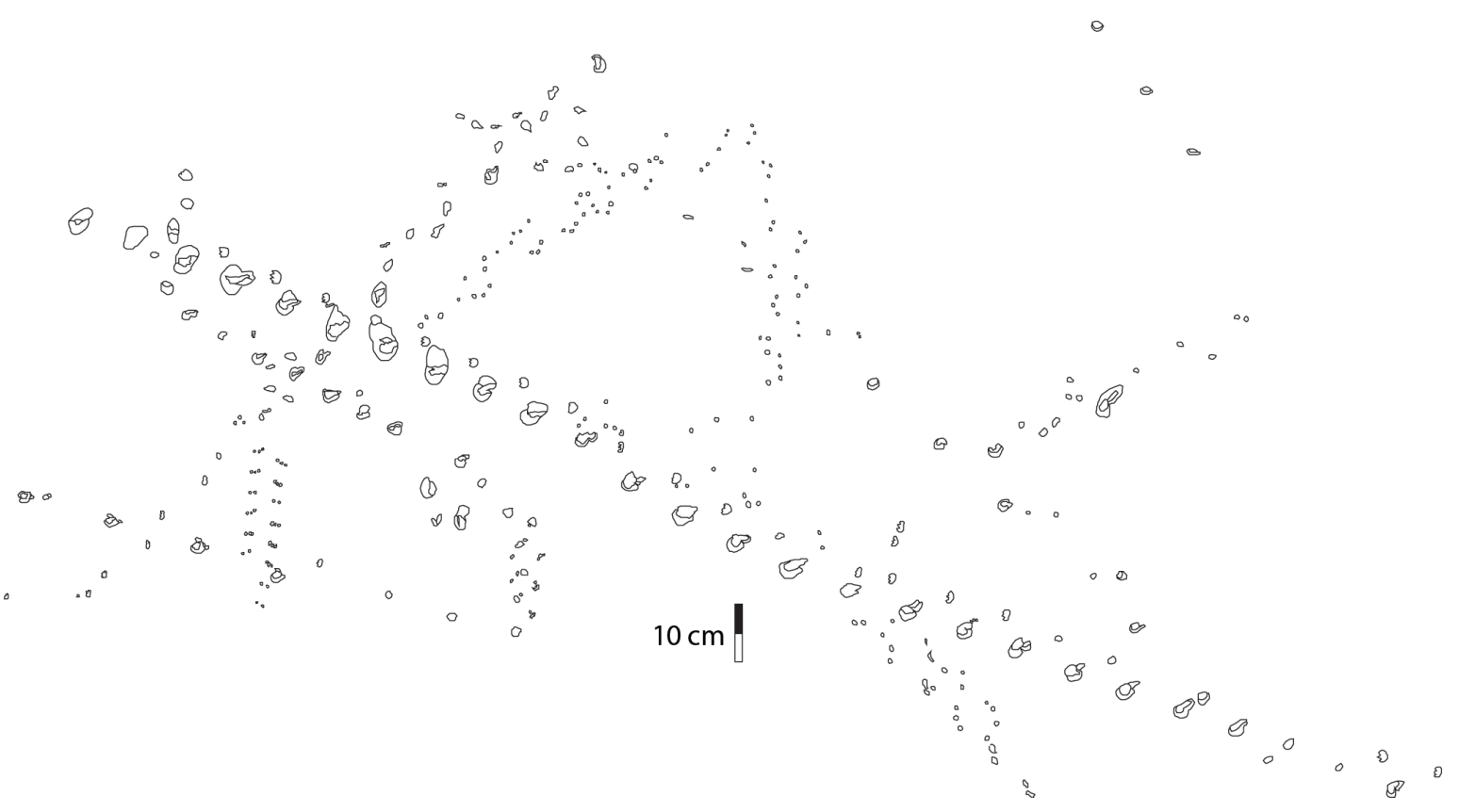

FIGURE 6. Map of 490, based on composite photo in Figure 5 . Scale bar equals $10 \mathrm{~cm}$ in $5 \mathrm{~cm}$ increments. 

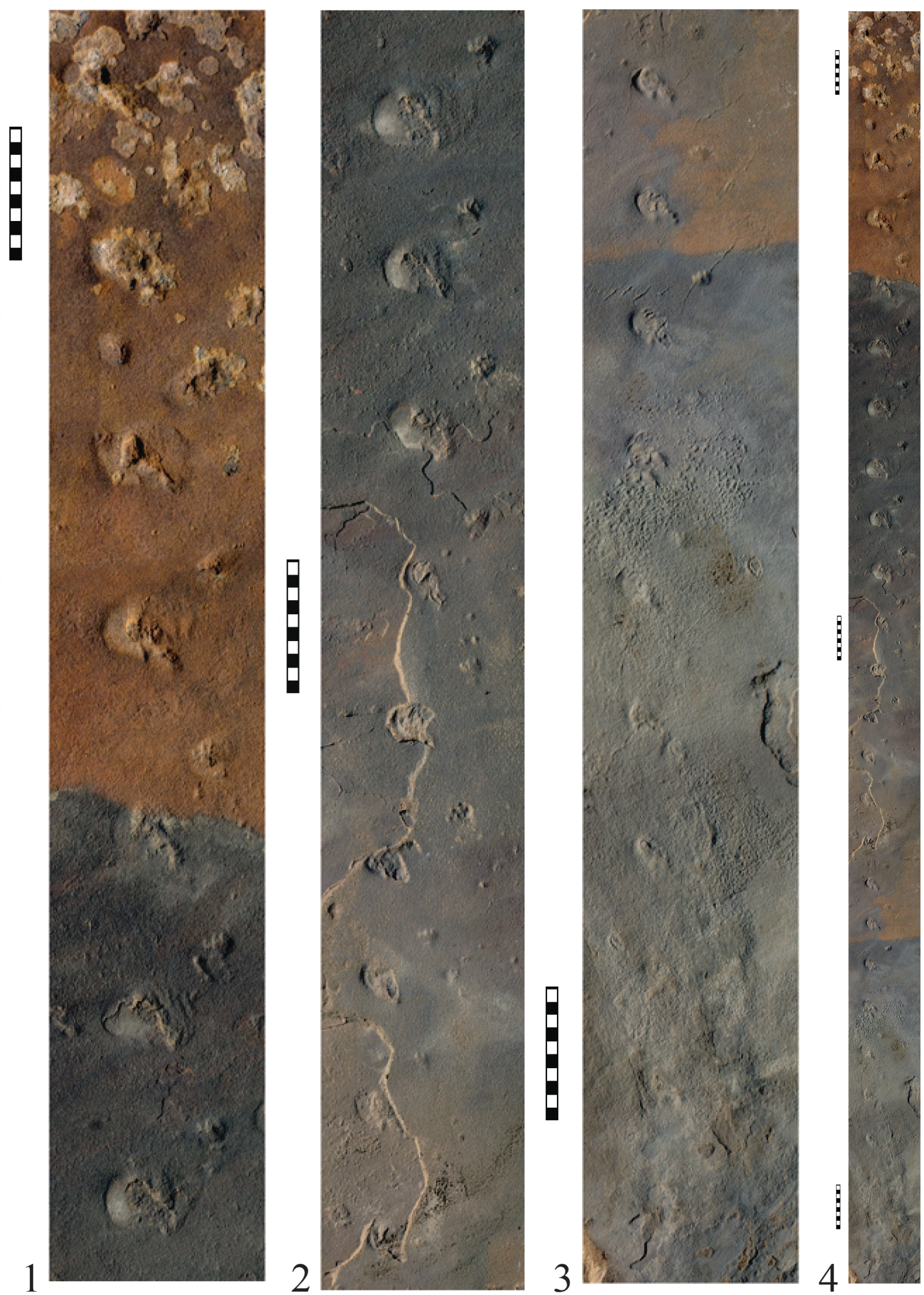

FIGURE 7. Composite image of the long transverse trackway at DNM 490 presented in 3 parts and the entire trackway. In each case, the trackway is oriented so that left (west) end is to top of page and upslope is to right of page. 1, left (west) end of the trackway. 2, section of the trackway adjacent to and to the right (east) of the section in Figure 7.1. 3, section of the trackway adjacent to and to the right (east) of the section in Figure 7.2. 4, the entire composite image of the trackway. Scale bars equal $10 \mathrm{~cm}$. 

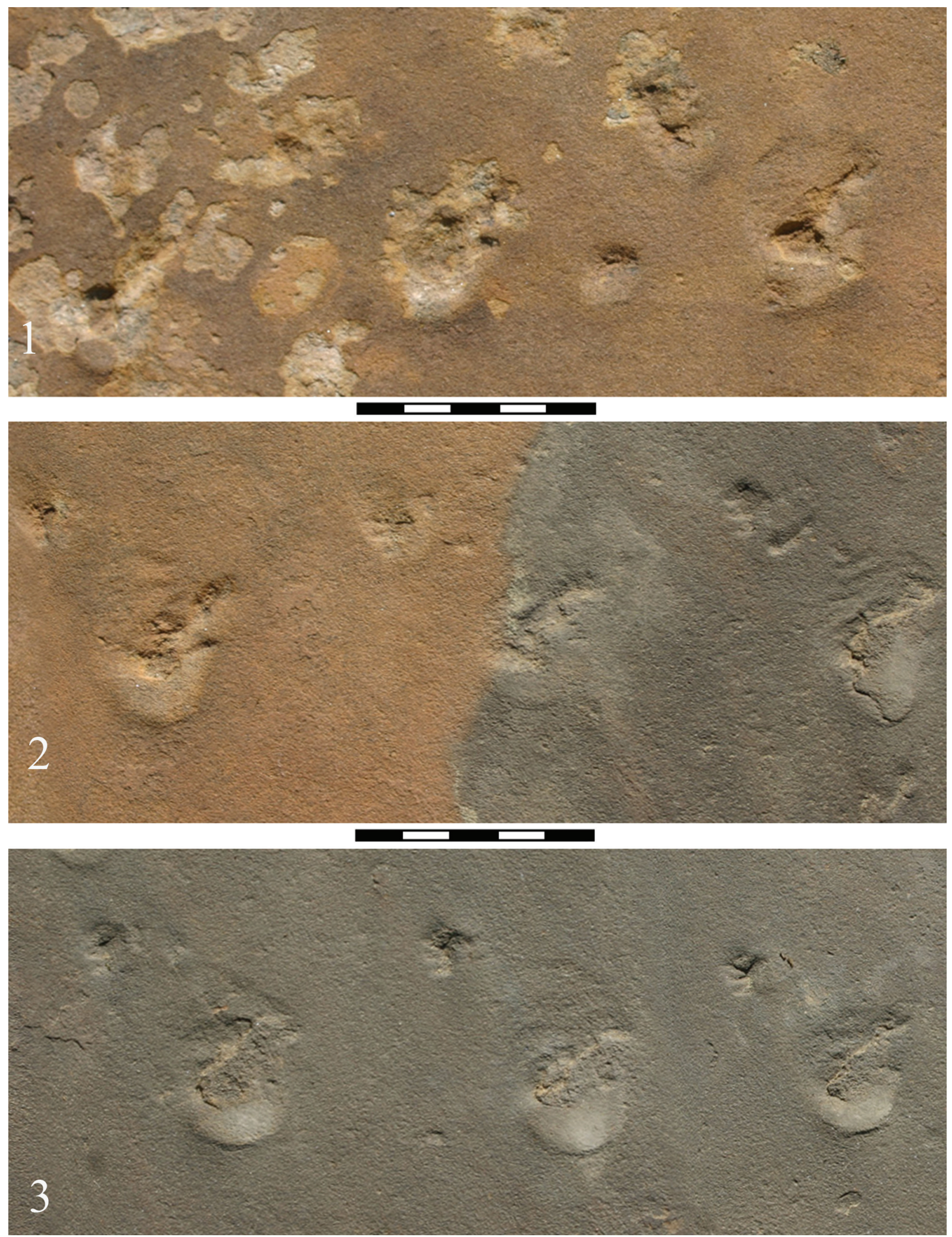

FIGURE 8. Transverse trackway from locality 490, in sections. These are enlargements of sections of the composite photo in Figure 7. Sections do not overlap, but do abut one another. 1, left side of trackway (cf. with Figure 6) is the top section. 2, the next section in the trackway, adjacent to and to the right of Figure 8.1. 3, the next section in the trackway, adjacent to and to the right of Figure 8.2 . Scale bars equal $5 \mathrm{~cm}$. 

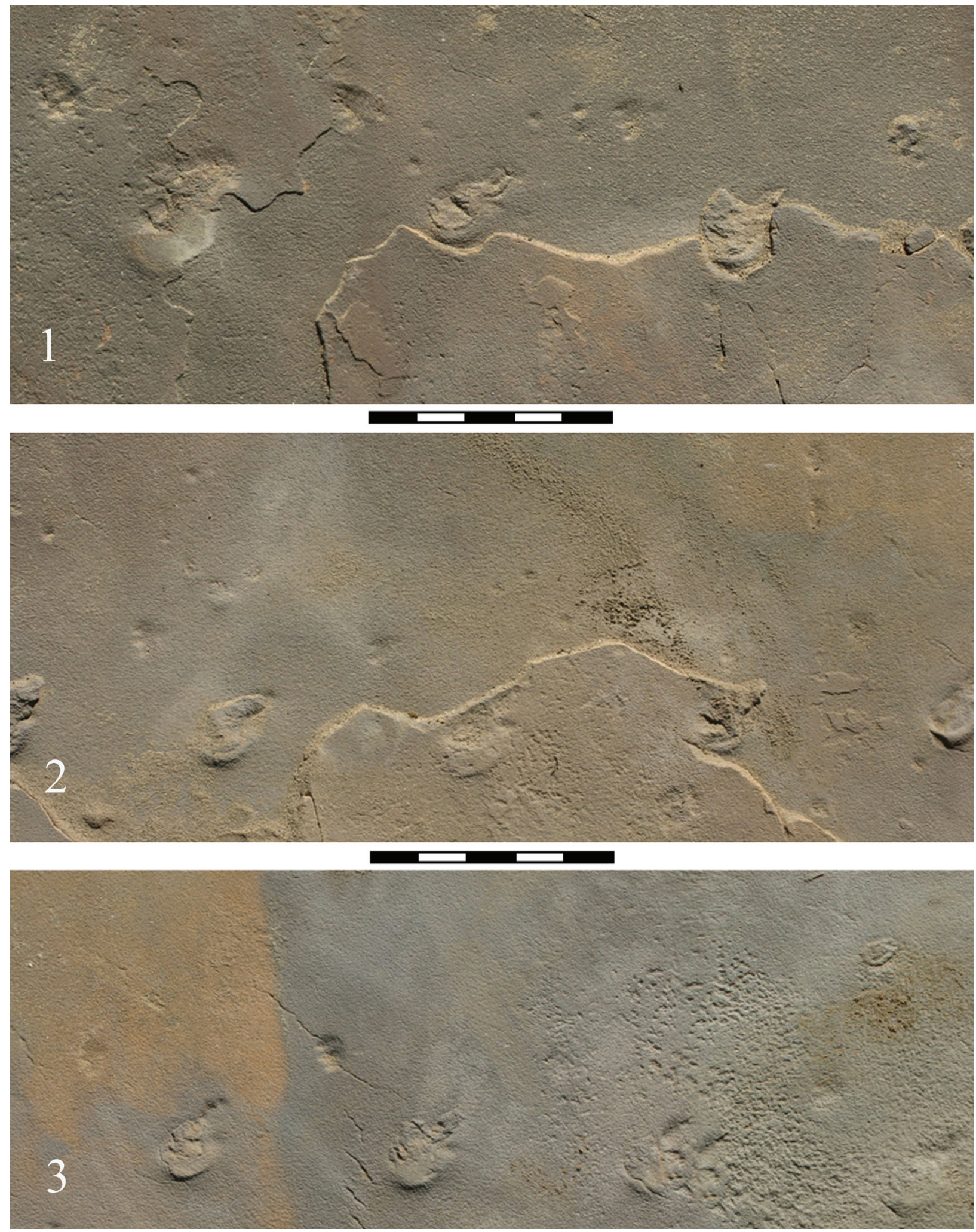

FIGURE 9. Transverse trackway from locality 490, in sections. These are enlargements of sections of the composite photo in Figure 7. Sections do not overlap, but do abut one another. 1, the next section in the trackway, adjacent to and to the right of Figure 8.3. 2, the next section in the trackway, adjacent to and to the right of Figure 9.1. 3, the next section in the trackway, adjacent to and to the right of Figure 9.2. Scale bars equal $5 \mathrm{~cm}$. 

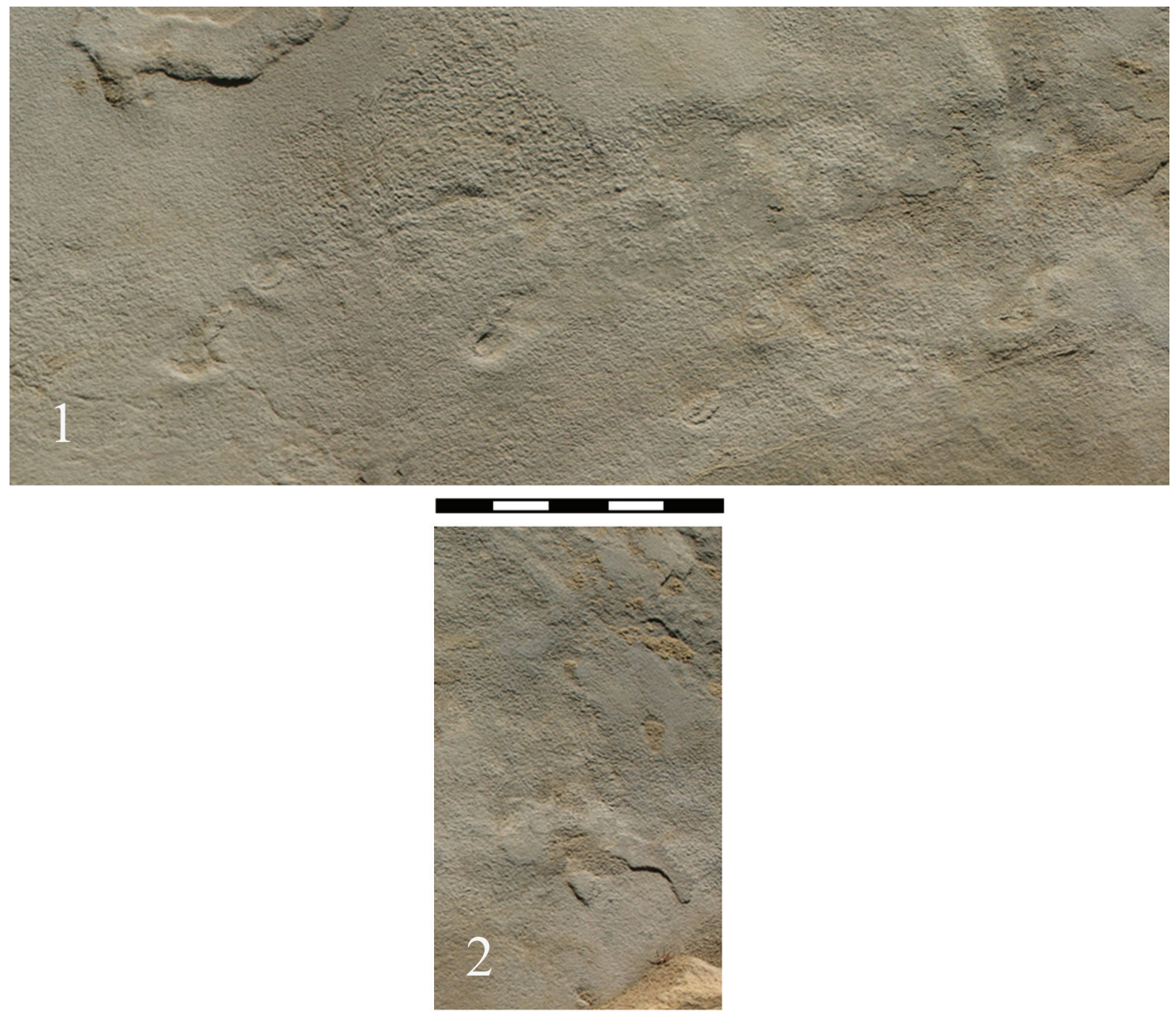

FIGURE 10. Transverse trackway from locality 490, in sections. These are enlargements of sections of the composite photo in Figure 7. Sections do not overlap, but do abut one another. 1, the next section in the trackway, adjacent to, and to the right of Figure 9.3. 2, the next section in the trackway, adjacent to and to the right of Figure 10.1. Scale bar equals $5 \mathrm{~cm}$.

of the track. A push-up rim with a short, curved profile defines the downslope margin of the track. Such tracks are typical of those found on track surfaces and comprise the majority of tracks on UUIC 1873.

In contrast, the tracks we interpret as having been made during downslope travel rarely preserve any details of foot morphology, and the greater part of the track consists of two distinctive features developed marginal to the actual impression of the foot. The first is a flat-topped raised, arcuate platform we shall refer to as a pressure pad, following the use of Fornos et al. (2002), which extends from the downslope margin of the depression made by the foot. The second is a shal- low depression with an arcuate margin and congruent crescentic ridges across its surface as the upslope part of the track. In UUIC 1873, the features of the tracks are preserved in deep red sandstone; the small depressions left by the removal of the animals' feet in the downslope tracks, however, are filled by lighter colored sand, making them clearly distinguishable. In at least two of these tracks, the impression of digits along the anterior margin of the foot impression is consistent with our interpretation of the orientation of these tracks. This morphology is very consistent through all the tracks in the downslope trackways. Because the greater part of the track is the result of disturbance around the actual impression of the foot, the tracks 


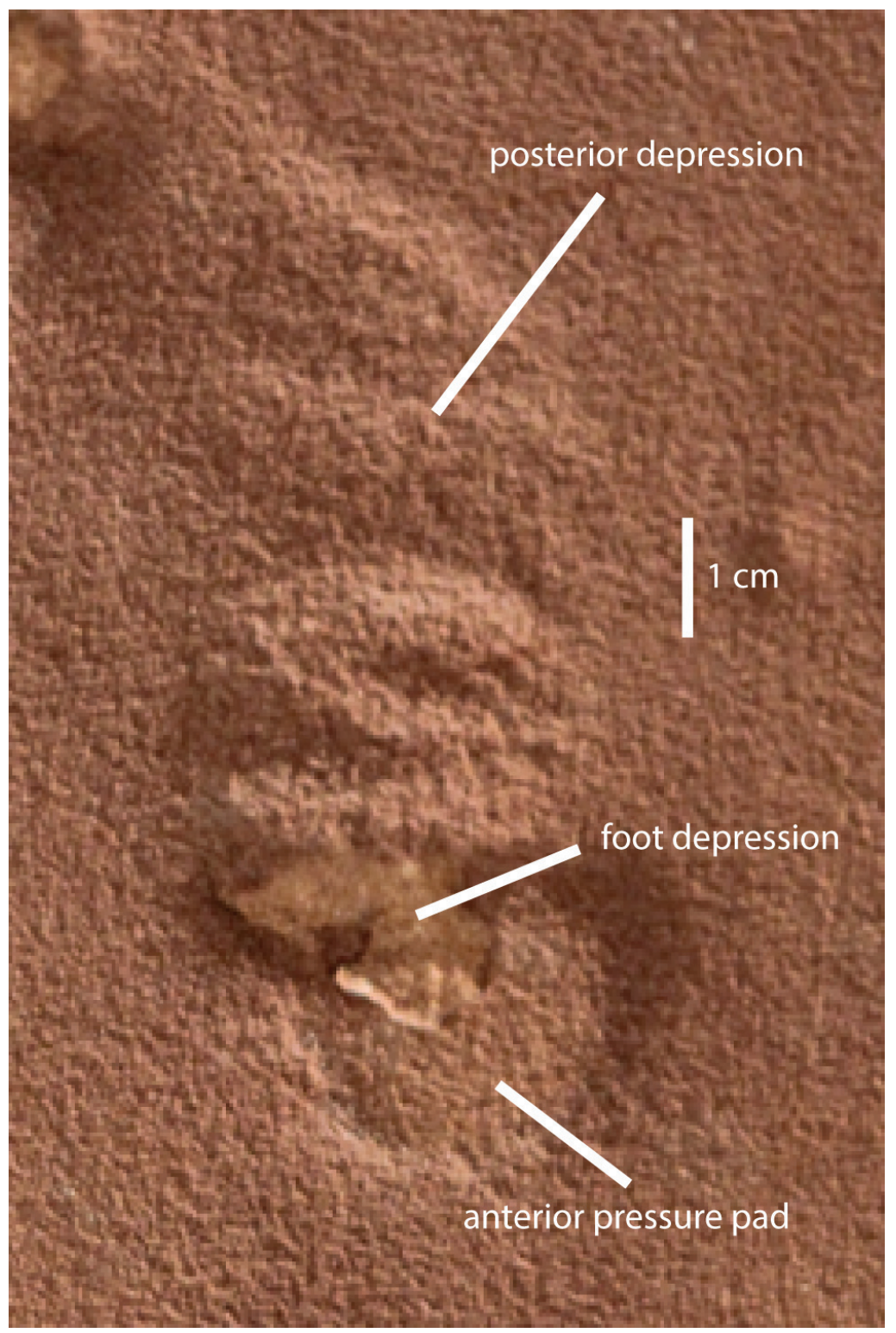

FIGURE 11. Detail of a track from the downslope trackway along the right side of UUIC 1873. The location of this figure is indicated by the small rectangle in Figure 3. Note the anterior platform, the posterior, slumped depression, and the small space for the foot filled with lighter colored sand.

vary somewhat in size, especially as measured along the long axis of the track, and in relative proportions of the different elements of the track. One track that is well preserved and clear of interference with other traces (Figure 11) is $65 \mathrm{~mm}$ total length along its longest axis, $19 \mathrm{~mm}$ along the anterior/downslope pressure pad, $11 \mathrm{~mm}$ along the depression left by the foot, and $35 \mathrm{~mm}$ along the posterior/upslope depression.

One of the two longer downslope trackways (right side of the slab) exhibits a change of gait and shortening of the stride evident in a section in the middle of the trackway (Figures 2, 3, 12). From the point where the trackway enters the slab surface, there are eight (four left, four right) steps that are equally spaced. Then there is an abrupt shortening of stride length for 2.5 paces (two left, three right) before the trackway continues with lengthening strides. Not only are these five tracks more closely spaced, but it is also among these tracks that impressions of the digits are preserved, and manus tracks can be distinguished by small anterior pressure pads anterior to the pressure pads of the pes (Figure 12). 


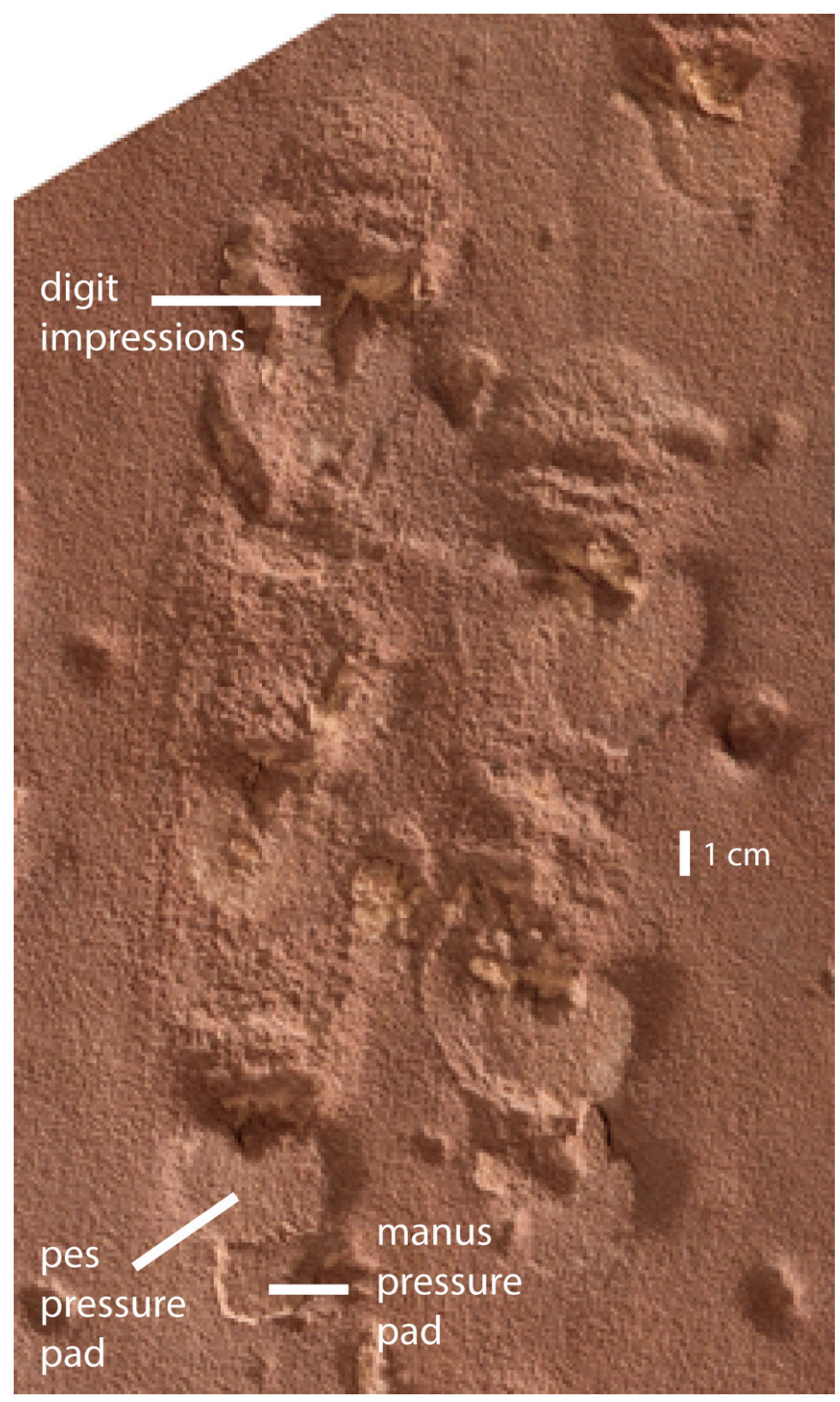

FIGURE 12. Segment of the trackway along the right side of UUIC 1873 that shows closely spaced tracks. The location of this figure is indicated by the large rectangle in Figure 3. Note also the impressions of digits on two of the tracks and the smaller anterior platforms of the manus tracks immediately anterior to the pes tracks.

We interpret the parts of the downslope tracks described above as the result of a two-step process driven by the animal planting and withdrawing its foot. First, as the foot is planted, a mass of sand is displaced forward and upward along a low-angle slip surface (a thrust fault). The sand is lifted up slightly to create the flat-topped pressure pad, the anterior or downslope part of the track. Second, as the foot is withdrawn, the sand up slope from the foot impression loses its support and collapses as a small scale mass wasting event in which the sand slumps, rotating along curved slip planes. The resulting depression crossed by crescentic ridges that mark the slip surfaces forms the posterior/upslope part of the track. The impression of the foot itself usually does not reveal a clear outline because the anterior margin, which would show the digits is the deepest part of the track and perhaps extends under the edge of the pressure pad of displaced sand, and the posterior part is buried 
by the slumping sand. A few tracks, however, do show features that look like the impressions of toes along the anterior margin of the foot impression (Figure 10), corroborating our interpretation of the direction of travel.

\section{Related Studies}

The anterior pressure pad is attributed to displacement of a mass of sand forward and slightly upward along a low angle slip surface. This feature is seldom seen and has not been reported in track literature, although there have been reports of similar features produced by related processes. Fornos et al. (2002) described trackways of Myotragus preserved in Pleistocene dune sands. The morphology of these tracks is diverse, but none duplicates the features observed on the downslope tracks of UUIC 1873. There are, however, some similar features. Fornos et al. (2002) used the term "pressure pads" for features that share some characteristics with the features we have observed in the downslope Brasilichnium tracks and are probably formed by related processes. Therefore, we have followed this usage in referring to them as anterior pressure pads. Like the anterior pressure pads, the pressure pads associated with the Myotragus tracks are small masses of sand displaced upward and outward along curving slip surfaces in response to the forceful intrusion of the hoof of the animal into the sand. Unlike the anterior pressure pads, however, the Myotragus pressure pads usually occur as several, narrow ridges separated by the curved slip surfaces along which they moved. These pressure pads may form symmetrically around tracks made on a level surface, but are preferentially developed on the downslope side of tracks made on a slope, regardless of the direction of travel. One reason for the typical occurrence of multiple pressure pads appears to be the steeper angle of the slip surfaces that separate them and the resulting tendency of the plane of thrusting to step outward as the foot was forced deeper into the sand. In contrast, the single, anterior pressure pad appears to be the result of displacement along a single, low-angle slip surface driven by a shallower penetration by the foot, which delivered a force directed more tangentially to the surface. These differences could be the result of the great difference in the size of the trackmakers and, perhaps especially, the difference in the shape of the foot and resulting force per unit area delivered to the substrate. In other words, the Myotragus feet were driven more deeply and more forcefully into the sand, in both absolute and relative terms.
Theropod dinosaur tracks studied by Graversen et al. (2007) also show features that indicate a process similar to that which produced the anterior pressure pads in UUIC 1873. By identifying slip planes and the masses of sand bounded by them, they were able to recognize disturbed areas which they called thrust ramp systems that extended posterior to the posterior margin of the foot impression itself some considerable distance. These thrust ramp systems represent masses of sand that have been displaced backward (horizontally) and slightly upward along low angle thrust faults in response to a largely horizontally directed force. This is somewhat comparable to the mechanics of the formation of the anterior pressure pad in the UUIC 1873 tracks, but in this case the horizontal thrust results from the propulsive phase of the stride of the theropod walking on a level surface, creating the thrust ramp systems on the posterior margin of the track. Because the theropod tracks studied were undertracks, the surface morphology was not preserved and cannot be compared with the Nugget tracks. But in their reconstruction of the track development, it seems likely that there were at least two disks of displaced sand, making them more like the concentric pressure pads described by Fornos et al. (2002). Graversen et al. (2007) interpreted the progressive increase in propulsive force as the cause of development of successive thrust faults. This may be an important difference from the sudden application of force in the impact of the downhill footfall of the Nugget trackmaker.

The posterior/upslope depressions seen in the downslope tracks of UUIC 1873 interpreted as a small scale slumps have not been previously reported. The crescentic ridges separated by parallel troughs descend stepwise from the arcuate posterior margin. It has all the characteristics of a small-scale landslide that has developed by sequential slumping. The ridges are small, rotated sand bodies, and the troughs indicate the position of the slip planes.

\section{Insights from Locality $\mathbf{4 9 0}$}

As uncommon as the morphology of the downslope tracks of UUIC 1873 appear to be, essentially the same features are present in the tracks of the long trackway at locality 490 . This trackway was made by an animal that was not travelling down slope, but that traversed the slope, ascending only very gradually. In these tracks, the pressure pad is formed along the downslope margin rather than the anterior margin of the track, and the slumped depression is on the opposite, ups- 
lope side of the track. The orientation of these features appears to be entirely determined by slope direction and little affected by the propulsive force of the animal's stride. As in the downslope tracks, when the downslope foot of the track maker struck the substrate, the greater part of the force was directed down slope at a low angle to the surface, producing a downslope pressure pad of sand, and as the foot was withdrawn, the destabilized slope above slumped into the track.

Some features of the long trackway at locality 490 raise interesting questions about, and perhaps provide insights into, the formation and preservation of downslope tracks such as those in UUIC 1873. The trackway crosses an interval where a sediment lamina, 2-3 mm thick, has spalled off the outcrop exposing the surface below. Most of the trackway is preserved on the uppermost layer preserved, but the portions that cross the spalled area of the outcrop represent undertracks from only a small increment of sediment below that layer. Loss of this small thickness of sediment results in a significant difference in the morphology of the tracks. The undertracks lack the flat-topped downslope pressure pad. Instead, the downslope margin of the track is marked by a push-up rim with a gently curved profile of much more limited lateral extent. This morphology is more similar to the simple push-up rims seen in most upslope tracks. In addition, there is no trace of the slumped upslope depression in the undertracks. One fact that is apparent from the difference in track morphology expressed in the different layers is that the downslope pressure pad and upslope slump depression appear to be confined to a very thin (approximately 1-3 $\mathrm{mm}$ ) lamina.

The transverse trackway at locality 490 preserves both left (downslope) and right (upslope) tracks. The left and right tracks are strongly asymmetrical. The downslope tracks are more deeply impressed and cause greater sediment disturbance surrounding the impression of the foot. In contrast, the upslope tracks are very shallowly impressed and simple in morphology. These upslope tracks preserve only the outline of the foot with a weakly developed push-up rim that is posterior to the track rather than on its downslope margin. Because the downslope foot would have borne most of the weight of the animal, the tracks they produced would be expected to be more strongly developed than the upslope tracks. The upslope foot may have been used less for support than for balance and propulsion.
The downslope tracks preserve both manus and pes tracks. The manus and pes are not well separated, but can be readily distinguished. The pes placement is downslope and anterior to the manus, partly obscuring it. No doubt this is the result of gravitational acceleration across the line of travel, shifting the path of the animal's body as it walked. Both manus and pes tracks have downslope pressure pads and upslope slump depressions that have merged to some extent, but that can still be distinguished. For the upslope tracks, only a single track, presumably the pes impression, represents each stride. Absence of manus tracks could be explained by overprinting by the pes, but given the offset of manus and pes in the downslope tracks it seems likely that there would be separation between the manus and pes in the upslope tracks for the same reason. Another possible explanation for the absence of manus tracks in the upslope side of the trackway is that these tracks are undertracks, and the fainter manus impressions were only present in a higher layer that is not preserved. The upslope tracks exposed in the segments of the trackway where a layer has spalled off are markedly shallower and less distinct than those in the layer above, illustrating how quickly these faint impressions can fade with depth. If the upslope tracks present on the uppermost preserved layer are undertracks, then the downslope tracks must be as well. This is entirely possible, although it seems surprising that the fine detail of the surface of the slump depression and the level surface of the pressure pad do not represent the original substrate surface. It also seems surprising that the uppermost increment of sediment on which the tracks were originally impressed is nowhere preserved. One possible explanation for this is that the most superficial sediment on which the tracks were made was loose, dry sand and was removed by the wind prior to the next preserved increment. The differences in features preserved in tracks exposed on the two different laminae in this trackway show that features can be confined to very thin laminae, and that significant changes in morphology can occur from one layer to the subjacent surface. Therefore, there is some degree of independence in the response of sediment to track formation from layer to layer.

\section{OTHER NUGGET SANDSTONE DOWNSLOPE TRACKWAYS}

Another dune foreset, downslope trackway is on one of two slabs figured by Buss (1921). Both slabs are from the Nugget Sandstone in the area of 
Heber, UT. At the time Buss was in the Department of Geology at Brigham Young University in Provo, UT. A search of the collections in the BYU Department of Geology and the BYU Museum of Paleontology failed to turn up either the specimens or any data associated with them, so their whereabouts are unknown. Although Buss's photographs are not of high quality (Figure 13), a few relevant observations can be made. The trackway compares quite well with the downslope tracks on UUIC 1873. The trackway consists of 12 alternating tracks, all of which appear to be pes impressions. The original (depositional) dip of the slab cannot be determined from the photos, but based on UUIC 1873, each track has a large, smooth pressure pad at its downslope margin and a pronounced depression with crescent, ridges on the upslope margin.

Lockley (2005) briefly mentioned and figured a downslope trackway from the Iceberg Canyon site in the Navajo Sandstone. However, he did not identify the track as either bipedal or quadrupedal, and the drawing of the trackway is insufficient for comparison with the sediment distortion seen in UUIC 1873 and the transverse trackway at locality 490. Finally, given the large size of those tracks it is unlikely that they are Brasilichnium, even if quadrupedal.

\section{DISCUSSION}

Vertebrate tracks are common fossils in eolian deposits from the Carboniferous through the Holocene (McKeever, 1991). Those on dune foreset beds are virtually all made by animals walking up slope. Gilmore $(1927$, p. 3) noted that of the hundreds of Coconino Sandstone tracks he had examined only three that were not upslope tracks. A similar pattern is present in the Nugget, Navajo, and Aztec sandstones (Lockley, 2005; Engelmann and Chure, 2011; Rowland and Mercadante, 2014). Fornos et al. (2002) described abundant tracks of the goat Myotragus balearicus in Pleistocene dune foreset beds on the island of Mallorca, but downslope tracks are rare at that site as well (Fornos, personal commun., 2013). Thus, there is a puzzling pattern of an absence of downslope trackways on dune slip faces either in isolation or on surfaces with abundant upslope trackways. This pattern holds across a wide phylogenetic and temporal scale (from Late Paleozoic synapsids/mammaloids to Pleistocene goats). Although various biological and environmental explanations for this pattern have been proposed (see discussion below), no consensus has appeared. The analysis of trackway formation and dynamics has become

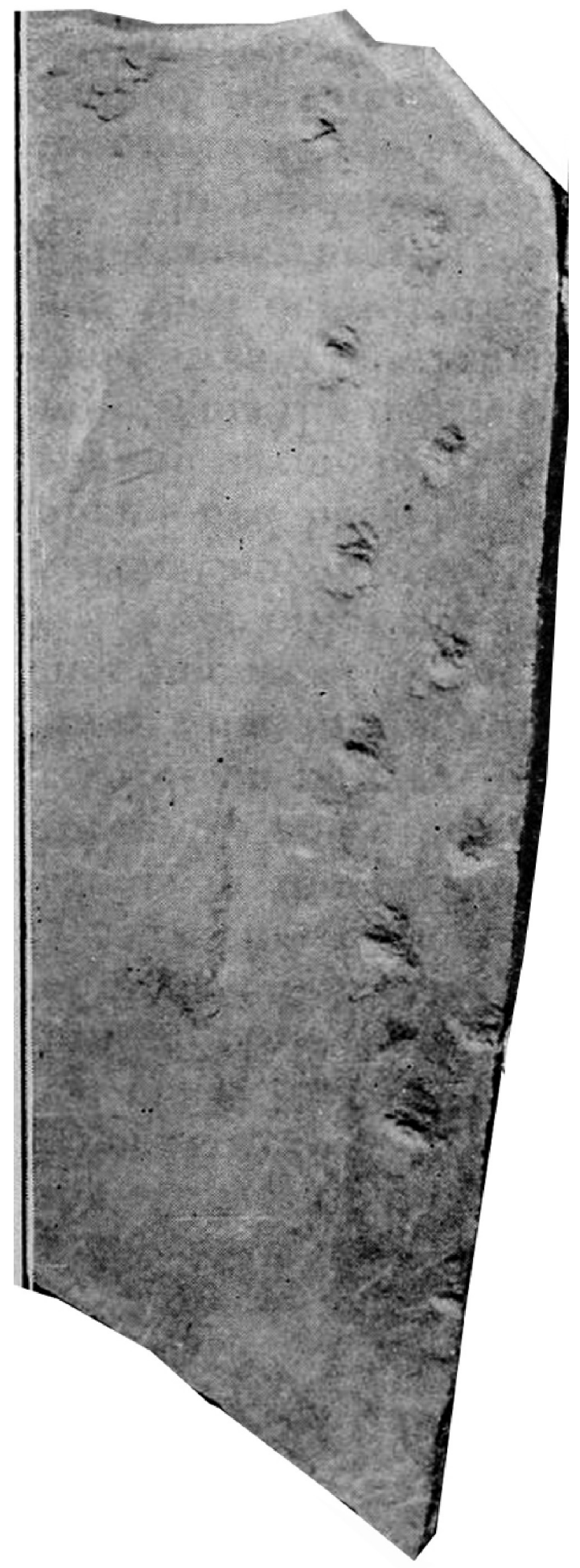

FIGURE 13. Reproduction of part of the photograph from Buss (1921). The original figure has been cropped to show only the Brasilichnium trackway and rotated $180^{\circ}$ to show the tracks in what we interpret to be their original vertical orientation. No scale in photo, but based on Buss' description, the block is slightly less than $1 \mathrm{~m}$. 
increasingly sophisticated (Milan et al., 2004; Graversen et al., 2007; Jackson et al., 2009), but much of that work focuses on dinosaur tracks and tracks in horizontally bedded sediments.

Track formation and preservation on dune foresets, especially those in the Permian Coconino Sandstone, have long attracted the attention of paleontologists. Integral to the studies of how these tracks were formed was the explanation for the rarity of downslope tracks. McKee $(1944,1947)$ experimented with living side-blotched lizard (Uta), the spiny lizard (Sceloporus), and the common chuckwalla (Sauramalus ater) walking on variously inclined sandy slopes with varying amounts of moisture in the sand. He investigated both the best slope for preservation as well as how the tracks were preserved. Unexpectedly, McKee found that the best defined tracks were formed in dry, rather than moist sand. In his dry sand experiments he used very fine sand, but noted that other sands did not significantly change the results. Both upslope and downslope tracks were well defined at $12^{\circ}$, the approximate maximum angle of dune stoss slopes. At an angle of $28^{\circ}$, a common angle on dune lee slopes, uphill tracks were well developed, but slumping destroyed downslope tracks. At $33^{\circ}$, the angle of repose for the sand he was using, the slumping and sliding destroyed most upslope and all downslope tracks. Based on his experiments, McKee concluded that the predominance of upslope tracks on dune foreset beds was because they formed on slopes between 28-30 $0^{\circ}$ where uphill tracks are well developed and preserved but downslope tracks are obliterated by slumping.

In support of his explanation for the absence of downslope tracks, McKee (1944) cited Reiche (1938, p. 918) who observed that tracks of coyotes, rabbits, and lizards on modern dunes after a rain lead up slope "without exception," but that downslope tracks were "obscured by sliding of the surface layers of sand." Reiche offered a single example of a continuous trackway made by a rabbit ascending and descending the lee slope of a dune leaving clear upslope tracks and obscuring the downslope tracks along its path as evidence for this generalization. Reiche did not report what the dip of that dune slip face was nor how high up the tracks occurred. In addition, his observations were made after a rain, rather than in dry sand.

Based on McKee's work, we would expect that well-preserved upslope and downslope tracks would be present well out on distal regions of the foresets with an original dip of $12^{\circ}$ or less. Vaughn (1963) described an isolated downslope trackway from foreset beds in the De Chelly Sandstone, where the original dip of the bed was $17-18^{\circ}$. However, such bedding surfaces are generally unknown in Permian through Early Jurassic dune deposits, with the possible exception of UUIC 1873 , but the original dip of that slab is unknown. Furthermore, we would expect to see trackways in this area of the dune face to be less likely to have a preferred orientation, i.e., trackways should run perpendicular, and at other angles, to original dip. However, such trackways are extremely rare, based on literature reports.

McKee's (1944) upslope and downslope lizard trackways were made on separate areas of the slope in his experimental setup, so it is unknown whether or not an animal coming down a slope already containing upslope tracks would destroy those upslope tracks. We expect that they would. If so, then such destruction should be seen on Nugget surfaces with numerous upslope tracks, possibly expressed as irregular blank strips running approximately parallel to dip, but it is not (Engelmann and Chure, 2011; Rowland and Mercadante, 2014).

Although McKee reported that downslope tracks made during his experiments were "destroyed," he did not publish any photos documenting the downslope track trials. We are uncertain as to whether those tracks were completely unrecognizable or that they left some disturbance of surface sediment that might be identified as a place where an animal had proceeded downhill. Furthermore, given what is known about the complexity of underprints in vertebrate trackways on dune foreset beds (Fornos et al., 2002), it is possible that while a downslope track itself might not be identifiable, its underprint might be recognizable in vertical or transverse sections.

An alternative explanation for the absence of downslope tracks is that the trackmakers came down the dune by a different path than the one they went up slope on. For example, there may be a behavioral preference for the trackmakers to descend from the dunes along the crests or the more gently sloping upwind surfaces, which are not preserved. However, that is difficult to test with ichnofossils, and we know of no reports of such behavior in modern desert vertebrates. Another way in which behavior could bias the record was suggested by Rowland and Mercadante (2014) who proposed that gregarious behavior in therapsids may account for parallel upslope Brasilichnium trackways. This could act as a multiplier to increase the disparity in the track record. 
McKee's interest in tracks was to understand the ichnology of the Coconino Sandstone. The lizards in his experiments approximated the estimated size and weight of the Coconino trackmakers and left similar track impressions. However, lizards may not be good models for the Brasilichnium trackmaker. Brasilichnium tracks are broader than long with short stubby digits (as opposed to hands and feet longer than broad and with long, thin digits as in lizards). Brasilichnium trackways also differ in not showing tail drag marks. This may be a reflection of the semi-upright posture of therapsids as opposed to the sprawling posture of lizards. How these significant differences might affect track making and preservation is unknown. It may be that the more compact structure of the manus and pes in Myotragus and the Basilichnium trackmaker result in deeper penetration of sediments with greater force per unit area than in forms with a lizard-like manus/pes structure. However, the pressure pads seen in UUIC 1873 and the transverse trackway at locality 490 are not present in either Coconino tracks or McKee's experimental trackways, nor are those features seen in a $1.5 \mathrm{~m}$ downslope trackway described by Vaughn (1963), which has lizard like tracks with long toes. However, downslope pressure pads are present in goat (Myotragus) up and downslope trackways on Pleistocene dune foresets in Mallorca (Fornos et al., 2002).

Given the rarity of downslope trackways on dune lee slopes, it is ironic that the first reported vertebrate ichnofossil from the Nugget Sandstone should be of just such a trackway (Buss, 1921), although it was unrecognized as such at the time. Unfortunately that specimen cannot now be located at BYU and, despite all the subsequent ichnological field work done in the Nugget, Navajo, and Aztec sandstones, it would be almost 90 years before another such Nugget trackway was discovered, this time on display in the halls of the Frederick Albert Sutton Building at the University of Utah.

\section{APPENDICES}

Many details of the trackways described in this paper are best seen in large images, which are too big for the printable text version of this paper. We have provided full viewable Gigapan images of UUIC 1873 (Appendix 1) and the track surface at locality 490 (Appendix 3) at the Gigapan website and downloadable larger versions of Figures 2, 5, 6 , and 7 as appendices.

\section{ACKNOWLEDGMENTS}

We thank A.A. Ekdale (Department of Geology and Geophysics, University of Utah) for allowing us to study UUIC1873 under his care. B. Britt and R. Scheetz (BYU) searched for Buss' missing slabs at BYU. J. Panosky and K. Melstrom, volunteers in the NPS Geoscientists-in-the-Parks Program (run in partnership with the Geological Society of America's GeoCorps America ${ }^{\mathrm{TM}}$ Program), discovered DNM 490 while conducting a paleontological inventory of the Nugget Sandstone in DINO. M. Homan, A. Dineen, and D. Tarailo, also volunteers under the GIP/GCA program, assisted in molding the transverse trackway in the field and subsequently casting it. D. Vanosdall, a student at UNO helped with the photography of UUIC1873 and molding the transverse trackway in the field. GFE was supported in part by NPS CESU grant Paleontology and Paleoecology of the Early Jurassic Glen Canyon Group, Dinosaur National Monument (P09AC00207/J1404094676). The photographs of the Buss specimens are used courtesy of the Church History Library, The Church of Jesus Christ of Latter-Day Saints. We also thank the two anonymous reviewers of this paper for their valuable comments that have helped improve the final version.

\section{REFERENCES}

Albers, S.H. 1975. Paleoenvironment of the Upper Triassic-Lower Jurassic (?) Nugget (?) Sandstone near Heber, Utah. Unpublished Master of Science Thesis, University of Utah, Salt Lake City, Utah, USA.

Braddy, S.J. 1995. The ichnotaxonomy of the invertebrate trackways of the Coconino Sandstone (Lower Permian), northern Arizona, p. 219-224. In Lucas, S.G. and Heckert, A.B. (eds.), Early Permian Footprints and Facies. New Mexico Museum of Natural History and Science Bulletin 6. New Mexico Museum of Natural History and Science, Albuquerque.

Buss, F. 1921. Footprints on the sands of time. Improvement Era, 25:159-161.

Chure, D.J., Good, T.R., and Engelmann, G.F. 2014. A forgotten collection of vertebrate and invertebrate ichnofossils from the Nugget Sandstone (? Late Triassic - ? Early Jurassic), near Heber, Wasatch County, Utah, p. 181-195. In Lockley, M.G. and Lucas, S.G., (eds.), Fossil Footprints of Western North America. New Mexico Museum of Natural History and Science Bulletin 62. New Mexico Museum of Natural History and Science, Albuquerque.

Davis, R.B., Minter, N.J., and Braddy, S.J. 2007. The neoichnology of terrestrial arthropods. Palaeogeography, Palaeoclimatology, Palaeoecology, 255:284307. 
Dickinson, W.R. and Gehrels, G.E. 2010. Insights into North American paleogeography and paleotectonics from U-Pb ages of detrital zircons in Mesozoic strata of the Colorado Plateau, USA. International Journal of Earth Sciences, 99:1247-1265.

Engelmann, G.F. and Chure, D.J. 2011. Up, down, and sideways: abundant therapsid tracks on a dune slipface in the Nugget Sandstone (Early Jurassic) from near Heber, Utah, p. 105. In (editor unknown), Program and Abstracts of the 71st Annual Meeting of the Society of Vertebrate Paleontology. The Society of Vertebrate Paleontology, Bethesda.

Engelmann, G.F., Chure, D.J., and Loope, D.B. 2010. An occurrence of remarkably abundant Brasilichnium tracks (Nugget Sandstone, Early Jurassic, Dinosaur National Monument) and their environmental context, p. 642. In Geological Society of America (ed.), Geological Society of America, Abstracts with Programs, vol. 42, no. 5. Geological Society of America, Boulder.

Faul, H. and Roberts, W.A. 1951. New fossil footprints from the Navajo (?) Sandstone of Colorado. Journal of Paleontology, 25:266-274.

Fernandes, M.A. and Carvahlo, I. de S. 2008. Revisão diagnóstica para a icnoéspecie de tetrápode Mesozóico Brasilichnium elusivum (Leonardi, 1981) (Mammalia) de Formacão Botucatu, Bacia do Paraná, Brasil. Ameghiniana, 45:167-173.

Fornos, J.J., Bromley, R.G., Clemmensen, L.B., and Rodriguez-Perea, A. 2002. Tracks and trackways of Myotragus balearicus Bate (Artiodactyla, Caprinae) in Pleistocene aeolianites from Mallorca (Balearic Islands, western Mediterranean). Palaeogeography, Palaeoclimatology, Palaeoecology, 180:277-313.

Gilmore, C.W. 1927. Fossil footprints from the Grand Canyon, second contribution. Smithsonian Miscellaneous Collections, 80:1-78.

Good, T.R. and Ekdale, A.A. 2014. Paleoecology and taphonomy of trace fossils in the eolian Upper Triassic/Lower Jurassic Nugget Sandstone, northeastern Utah. Palaios, 29:401-413.

Graversen, O., Milan, J., and Loope, D.B. 2007. Dinosaur tectonics: a structural analysis of theropod undertracks with a reconstruction of theropod walking dynamics. Journal of Geology, 115:641-654.

Haubold, H. 1971. Ichnia Amphibiorum et Reptiliorum fossilium, Handbuch der Paläoherpetologie, Teil 18. VEB Gustav Fischer Verlag, Jena.

Haubold, H., Hunt, A.P., Lucas, S.G., and Lockley, M.G. 1995. Wolfcampian (Early Permian) vertebrate tracks from Arizona and New Mexico, p. 135-165. In Lockley, M.G. and Lucas, S.G. (eds.), Fossil Footprints of Western North America. New Mexico Museum of Natural History and Science, Bulletin 6. New Mexico Museum of Natural History and Science, Albuquerque.

Hunt, A.P. and Lucas, S.G. 2007. Tetrapod ichnofacies: a new paradigm. Ichnos, 14:59-68.
Jackson, S.L., Whyte, M.A., and Romano, M. 2009. Laboratory-controlled simulations of dinosaur footprints in sand: a key to understanding vertebrate track formation and preservation. Palaios, 24:222-238.

Kocurek, G. and Dott, R.H., Jr. 1983. Jurassic paleogeography and paleoclimate of the central and southern Rocky Mountains regions, p. 101-116. In Reynolds, M.W. and Dolly, E.D. (eds.), Mesozoic Paleogeography of the West-Central United States. Society of Economic Paleontologists and Mineralogists, Rocky Mountain Section, Denver, Colorado.

Leonardi, G. 1981. Novo icnogenero de Tetrápode Mesózoico da Formacão da Botucatu, Araraquara, SP. Anais da Academis Brasileira de Ciencias, 53:793-805.

Lockley, M.G. 1991. Tracking Dinosaurs: A New Look at an Ancient World. Cambridge University Press, New York.

Lockley, M.G. 2005. Enigmatic dune walkers from the abyss: some thoughts on water and track preservation in ancient and modern deserts. Canyon Legacy (Museum of Moab), 54:43-51.

Lockley, M.G. 2007. A tale of two ichnologies: the different goals and potentials of invertebrate and vertebrate (tetrapod) ichnotaxonomy and how they relate to ichnofacies analysis. Ichnos, 14:39-57.

Lockley, M.G. 2011. The ichnotaxonomic status of Brasilichnium with special reference to occurrences in the Navajo Sandstone (Lower Jurassic) in the western USA, p. 306-315. In Sullivan, R.M., Lucas, S.G., and Spielmann, J.A. (eds.), Fossil Record 3. New Mexico Museum of Natural History and Science, Bulletin 53. New Mexico Museum of Natural History and Science, Albuquerque.

Lockley, M.G. and Hunt, A.P. 1995. Dinosaur Tracks and Other Fossil Footprints of the Western United States. Columbia University Press, New York.

Lockley, M.G., Hunt, A.P., Haubold, H., and Lucas, S.G. 1995. Fossil footprints in the DeChelly Sandstone of Arizona: with paleoecological observations on the ichnology of dune facies, p. 225-233. In Lockley, M.G. and Lucas, S.G., (eds.), Fossil Footprints of Western North America. New Mexico Museum of Natural History and Science, Bulletin 6. New Mexico Museum of Natural History and Science, Albuquerque.

Lockley, M.G., Hunt, A.P., and Meyer, C.A. 1994. Vertebrate tracks and the ichnofacies concept: implications for palaeoecology and palichnostratigraphy, $\mathrm{p}$. 241-268. In Donovan, S.K. (ed.), The Palaeobiology of Trace Fossils: The Johns Hopkins University Press, Baltimore, Maryland.

Lockley, M.G., Tedrow, A.R., Chamberlain, K.C., Minter, N.J., and Lim, J.-D. 2011. Footprints and invertebrate traces from a new site in the Nugget Sandstone Lower Jurassic) of Idaho: implications for life in the northern reaches of the great Navajo-Nugget erg system in the western USA, p. 344-356. In Sullivan, R.M., Lucas, S.G., and Spielman, J.A. (eds.), Fossil 
Record 3. New Mexico Museum of Natural History and Science, Bulletin 53. New Mexico Museum of Natural History and Science, Albuquerque.

McKee, E.D. 1944. Tracks that go uphill. Plateau, 16:6172.

McKee, E.D. 1947. Experiments on the development of tracks in fine cross-bedded sand. Journal of Sedimentary Petrology, 17:23-28.

McKeever, P.J. 1991. Trackway preservation in eolian sandstones from the Permian of Scotland. Geology, 19:726-729.

Milan, J., Clemmensen, L.B., and Bonde, N. 2004. Vertical sections through dinosaur tracks (Late Triassic lake deposits, East Greenland) undertracks and other subsurface deformation structures revealed. Lethaia, 27:285-296.

Milligan, M. 2012. Sizing up titans - Navajo erg vs. Sahara erg, which was the larger sandbox? Utah Geological Survey Notes, 44:8-9.

Morales, M. and Haubold, H. 1995. Tetrapod tracks from the Lower Permian DeChelly Sandstone of Arizona: systematic description, p. 251-261. In Lockley, M.G. and Lucas, S.G. (eds.), Fossil Footprints of Western North America. New Mexico Museum of Natural History and Science, Bulletin 6. New Mexico Museum of Natural History and Science, Albuquerque.

Rainforth, E. 1997. Vertebrate Ichnological Diversity and Census Studies, Lower Jurassic Navajo Sandstone. Research report submitted in partial fulfillment of the M.S. degree, University of Colorado at Boulder, Boulder, Colorado, USA. http://phobos.ramapo.edu/ - erainfor/publications.html (Last accessed June 2015)

Rainforth, E. and Lockley, M.G. 1996. Tracking life in a Lower Jurassic desert: vertebrate tracks and other traces from the Navajo Sandstone, p. 285-289. In Morales, M. (ed.), The Continental Jurassic. Museum of Northern Arizona, Bulletin 60. Museum of Northern Arizona, Flagstaff.
Reiche, P. 1938. An analysis of cross lamination the Coconino Sandstone. The Journal of Geology, 46:905-932

Reynolds, R.E. 2006a. Jurassic tracks in California, p. 19-24. In Reynolds, R.E. (ed.), Making Tracks Across the Southwest. California State University, Desert Studies Consortium and LSA Associates, Inc., Zzyzx, California.

Reynolds, R. 2006b. Way out west: Jurassic tracks on the continental margin, p. 232-236. Harris, J.D., Lucas, S.G., Spielmann, J.A., Lockley, M.G., Milner, A.R.C., and Kirkland, J.I. (eds.), The Triassic - Jurassic Terrestrial Transition. New Mexico Museum of Natural History and Science, Bulletin 37. New Mexico Museum of Natural History, Albuquerque.

Rowland, S.M., Breithaupt, B.H., Stoller, H.M., Matthews, N.A., and Saines, M. 2014. First report of dinosaur, synapsid, and arthropod tracks in the Aztec Sandstone (Lower-Middle Jurassic) of Red Rock Canyon National Conservation Area, southern Nevada, p. 247-256. In Lockley, M.G. and Lucas, S. (eds.), Fossil Footprints of Western North America. New Mexico Museum of Natural History and Science, Bulletin 62. New Mexico Museum of Natural History and Science, Albuquerque.

Rowland, S.M. and Mercadante, J.M. 2014. Trackways of a gregarious, dunefield- dwelling, Early Jurassic therapsid in the Aztec Sandstone of southern Nevada. Palaios, 29:539-552.

Sadler, C.J. 1993. Arthropod trace fossils from the Permian DeChelly Sandstone, Northeastern Arizona. Journal of Paleontology, 67:240-249.

Stokes, W.L. 1978. Animal tracks in the Navajo-Nugget Sandstone. Contributions to Geology, University of Wyoming, 16:103-107.

Vaughn, P.P. 1963. A downslope trackway in the De Chelly Sandstone, Permian of Monument Valley. Plateau, 36:25-28.

Winkler, D.A., Jacobs, L.L., Congleton, J.D., and Downs, W.R. 1991. Life in a sand sea: Biota from Jurassic interdunes. Geology, 19:889-892. 


\section{APPENDIX 1.}

The full sized Gigapan image of UUIC 1873 (656 megapixels), presented at reduced size as Figures 1 and 2, can be viewed at the Gigapan website (http://www.gigapan.com/gigapans/174739) where the viewer can zoom to the maximum resolution at any part of the entire slab. The viewer should be aware that when viewed at this site the slab is oriented as displayed at the University of Utah.

\section{APPENDIX 2.}

The full size image reduced to create Figure 2. UUIC 1873 (824.8MB) rotated from as exhibited at the University of Utah to the orientation at the time of track formation. This file, append2.tif, can be downloaded from a folder in Box that can be reached with the link (https:// unomaha.box.com/s/yqehi4vgasbsdvgpaqo72ef3m8s20ay7).

\section{APPENDIX 3.}

The full sized Gigapan image of the track bearing surface at locality 490 (284 megapixels) can be viewed at the Gigapan website (http://www.gigapan.com/gigapans/174736) where the viewer can zoom to the maximum resolution at any part of the entire slab. Discoloration of transverse trackway is artifact of molding the trackway.

\section{APPENDIX 4.}

The full size image reduced to create Figure 5 viewable with the map in Figure 6 as an overlay. Composite photograph of the track-bearing surface of DNM 490 and outlines of tracks on an overlying layer (123.7MB). This file, append4.ai, can be downloaded from a folder in Box that can be reached with the link

(https://unomaha.box.com/s/yqehi4vgasbsdvgpaqo72ef3m8s20ay7).

\section{APPENDIX 5.}

The full size image reduced to create Figure 7. Composite image of the long transverse trackway at DNM 490 (89.4 MB). This file, append5.tif, can be downloaded from a folder in Box that can be reached with the link (https://unomaha.box.com/s/yqehi4vgasbsdvgpaqo72ef3m8s20ay7). 